\title{
Bir Ünlünün Rakip Marka Reklamlarında Yer Almasına Yönelik Tüketici Tutumlarının Belirlenmesi ${ }^{1}$
}

\author{
Doç. Dr. Zehra BOZBAY² - Öğr. Gör. Emine KARAKUŞ BAŞLAR ${ }^{3}$ - Gülçin ERDOĞAN ${ }^{4}$ \\ Vahideh ARGHASHi ${ }^{5}$
}

Başvuru Tarihi: 13.12.2019 Kabul Tarihi: 17.10.2020 Makale Türü: Araştırma Makalesi

\section{Öz}

Günümüzde markalar, reklamlarında ünlü kullanımına sıklıkla yer vermektedirler. Bu çalışmanın amacı genç tüketicilerin bir ünlünün aynı sektörde ve birbirine rakip olan markaların reklamlarında yer almasına yönelik tutumlarının keşfedilmesidir. Bu doğrultuda veri ve bilgilerin toplanmasında odak grup görüşmesinden yararlanılmıştır. Araştırmanın örneklem büyüklüğü 40 kişi olarak belirlenmiş olup bu kapsamda toplam dört adet odak grup görüşmesi gerçekleştirilmiştir. Verilerin analizinde içerik analizi yönteminden yararlanılmıştır. Araştırma bulguları, genç tüketicilerin tutumlarının ünlüye yönelik tutumlar ve ikinci markaya yönelik tutumlar olmak üzere ikiye ayrıldığııı ortaya koymuştur. Buna göre ünlüye yönelik tutumlar, inandırıcı bulmama, doğru bulmama, samimiyetsiz bulma, etik bulmama, para odakl bulma, olumsuz bulma, nötr bulma, farkında olmama, profesyonel bulma, markaya yönelik tutum ve olumlu bulma temaları altında toplanmıștır. İkinci markaya yönelik tutumlar ise olumsuz bulma, samimiyetsiz bulma, taklitçi bulma, etik bulmama, nötr bulma, profesyonel bulma, markaya yönelik tutum ve olumlu bulma temaları altında toplanmıştır.

Anahtar Kelimeler: Reklam, Ünlü Kullanımı, Rakip Firmalar, Kalitatif Araştırma, Odak Grup

Atıf: Bozbay, Z., Karakuş Başlar, E., Erdoğan, G. ve Arghashi, V. (2020). Bir ünlünün rakip marka reklamlarında yer almasına yönelik tüketici tutumlarının belirlenmesi. Anadolu Üniversitesi Sosyal Bilimler Dergisi, 20(4), 1-22.

\footnotetext{
${ }^{1}$ Bir önceki yıl dergiye yayın başvurusunda bulunulmuş makale olduğundan geriye dönük etik kurul izni gerekmemektedir.

2 İstanbul Üniversitesi, İșletme Fakültesi, Pazarlama Anabilim Dalı, zehrat@istanbul.edu.tr, ORCID: 0000-0002-2728-8003

3 İstanbul Esenyurt Üniversitesi, Meslek Yüksekokulu, Sivil Hava Ulaştırma İşletmeciliği Programı, eminekarakusbaslar@esenyurt.edu.tr, ORCID: 0000-0002-7090-4713

${ }^{4}$ İstanbul Üniversitesi, Sosyal Bilimler Enstitüsü, Pazarlama Anabilim Dalı Doktora Öğrencisi, gulcinerdogan@gmail.com, ORCID: 0000-0002-22142582

${ }^{5}$ İstanbul Üniversitesi, Sosyal Bilimler Enstitüsü, Pazarlama Anabilim Dalı Doktora Öğrencisi, argashv@yahoo.com, ORCID: 0000-0002-5528-5344
} 


\title{
Identifying Consumer Attitudes towards Celebrity Endorsement in Advertisements of Competing Brands
}

\author{
Assoc. Prof. Dr. Zehra BOZBAY - Lecturer Emine KARAKUŞ BAŞLAR - Gülçin ERDOĞAN \\ Vahideh ARGHASHI
}

\begin{abstract}
Nowadays, brands often use celebrities in their advertisements. The purpose of this study is to find out the attitude of young consumers about using celebrities in two rival companies' advertisements. In this regard, focus group is used to collect data. The sample size of this study is 40 people and a total of four focus group interviews were conducted. Content analysis used to analyze of the data. The study's findings show that the attitude of young consumers is divided into two parts: (1) attitude towards the celebrity, (2) attitude towards the second brand. According to the results, attitudes towards the celebrity include eleven dimensions are called unbelievable, inaccuracy, insincere, immoral, mercenary, undesirable, inactive, apathetic, professional, attitude and positive approach. Attitude toward second brand also include themes such as undesirable, insincere, impersonator, immoral, inactive, professional, attitude and positive approach.
\end{abstract}

Keywords: Advertising, Celebrity Endorsement, Rival Firms, Qualitative Research, Focus Group 


\section{Giriş}

Günümüzde özellikle güçlü markalar tarafından sıklıkla tercih edilen stratejilerden biri olan reklamda ünlü kullanımı, belirli bir hedef kitleye iletilmek istenen mesajların bir ünlüyle ilişkilendirilmesi yoluyla reklamın çekiciliğini ve akılda kalıcılığını artırarak bu tüketicilerin satın alma kararlarını etkilemeyi amaçlamaktadır. Bilhassa rekabetin güçlü olduğu sektörlerde, markaların belirledikleri hedef kitlelerinin zihninde rakiplerinden farklılaşmasını sağlayan, prestijli, havalı, genç, enerjik gibi ayırt edici marka imajı çağrışımlarına sahip olmak için reklamda ünlü kullanımı stratejisine sıklıkla başvurulmaktadır. Özellikle genç tüketicilerin yaygın olarak ideal benlikleriyle uyumlu olan çeşitli mesleklerdeki ünlüleri yakından takip ettiği ve o ünlülerin tercihlerini ciddiye aldıkları görülmektedir. Bu stratejinin marka farkındalığı aracılığıyla hedef kitlelerinin tutumlarını olumlu yönde etkileyerek başarıya ulaşmasında ise ünlünün kredibilitesinin, saygınlığının, fiziksel çekiciliğinin, ünlü ile markanın ürünleri ve hizmetleri arasındaki uyumun olması gibi çeşitli unsurlar önemli rol oynamaktadır.

Ülkemizde reklamda ünlü kullanımına ilişkin uygulamalar incelendiğinde ise kimi güçlü markaların rakiplerinin geçmiş yıllarda marka yüzü olarak kullandığ ünlüleri, ilerleyen yıllardaki iletişim çalışmalarında marka yüzü olarak tekrar seçtikleri gözlemlenmiştir. Literatürde ise bir ünlünün aynı sektörde ve birbirine rakip olan markaların reklamlarında yer almasına ilişkin tüketici tutumlarını inceleyen bir çalışmaya rastlanamamıştır. Bu noktadan hareketle, bu çalışmanın temel amacı 18-35 yaş arasındaki genç tüketicilerin bir ünlünün aynı sektörde ve birbirine rakip olan markaların reklamlarında yer almasına yönelik tutumlarının keşfedilmesi olarak belirlenmiştir. Gerçekleştirilen odak grup görüşmeleri sonucunda elde edilen bulguların gerek literatüre gerekse markaların pazarlama yöneticilerine reklamlarında yer verecekleri ünlülerin seçimi konusunda faydalı olması amaçlanmıştır.

\section{Kavramsal Çerçeve}

Bu başılk altında çalışmanın amacı doğrultusunda genç tüketicilerin bir ünlünün aynı sektörde ve birbirine rakip olan markaların reklamlarında yer almasına yönelik tutumlarının belirlenmesine yönelik olarak reklamlarda ünlü kullanımı ve reklamlarda ünlü kullanımına ilişkin tüketici tutumları konuları ele alınmıştır.

\section{Reklamlarda Ünlü Kullanımı}

Reklamlarda ünlü kullanımı, kurumsal marka imajını geliştirmek için büyük firmalar tarafından her zaman önemli bir stratejik yöntem olarak görülmektedir (Bower ve Landreth, 2001). Reklamlarda ünlü kullanımını açıklamak için yaygın olarak farklı disiplinlerdeki teoriler kullanılmaktadır. İletişim (Austin vd., 2008; Hung, 2014), antropoloji (McCracken, 1989), sosyal psikoloji ve bilişsel psikoloji (Ross vd., 1984) bu disiplinlere örnektir. Ünlü kullanımı pazarlama alanında da etkili bir yaklaşım olarak kabul edilmektedir (Spry vd., 2011, s.882).

Ünlüler, geniş bir toplumsal itibara sahip olan ve sosyal üyeler arasında iyi tanınmış kişilerdir (Erdogan, 1999). Dolayısıyla ünlüler, belirli bir grup insanın çoğunluğu tarafından takdir ve takip edilmekte olup hayranlarının ilgisini çekmektedir (Mittal, 2017). Bu kişiler, kendi kişisel başarıları ya da mesleki başarıları nedeniyle toplum içinde bilinen kişilerdir. Bir reklamcılık tekniği olarak kullanılan ünlü kullanımı ise, popüler kişiler aracıllğıyla bir ürünün reklamını yapmaktır (Bafna vd., 2016, s.222). Ünlü kullanımı sadece fiziksel ürünlerle sınırlı olmayıp hizmetleri ve fikirleri içermektedir (Pornpitakpan, 2004, s.62).

Günümüzde markalar sporcu, sinema oyuncusu ve popüler müzik şarkıcısı gibi farklı meslekleri olan ünlüler tarafından sıklıkla desteklenmektedir (Byberg vd., 2015). Tüketiciler bu ünlü kişilere yüksek düzeyde güvenmekte olup (Balakrishnan ve Kumar, 2011, s.108) bu güven sayesinde ünlülerin markalar hakkında 
söylediklerine inanmaktadırlar. Buna karşın, bir ünlü hakkındaki olumsuz bilgiler, ünlünün güvenilirliğini azaltmakta ve markaya karşı olumsuz tutumlara yol açmaktadır (Zhou ve Whitla, 2013, s.1017).

Reklamlarda ünlü kullanımının amacı, tüketicilerin reklam veren markaya veya ürünü satın alma kararına olumlu yön verilmesidir. Çünkü, günümüzde tüketiciler son derece sofistike, zeki ve eğitimlidir. İyi bir ürüne sahip olmak son derece rekabetçi pazarlarda büyüme için tek başına sürdürülebilir ve yeterli değildir. Ünlü kullanımı stratejik bir yöntem olarak firmaların bu amaca ulaşmasında yardımcı olmakta ve doğru bir şekilde tasarlanırsa firmalar açısından etkili sonuçlar doğurabilmektedir.

Carroll (2009) ile Ilicic ve Webster (2013) ünlülerin seçilmesinin önemli ve zorlu bir çalışma olduğunu belirtmişlerdir. Bir ünlünün isabetli seçilememesi, marka veya firma üzerinde ciddi düzeyde olumsuz bir etki oluşturabilmektedir (Louie ve Obermiller, 2002). Bu nedenle pazarlamacılar bu strateji aracılığıyla, markaları ile arzu edilen bir ünlünün imajı ve yaşam tarzı arasında bir bağlantı kurmaya çalışmaktadır (Suegker, 2003, s.64). Bu doğrultuda, çekici, güvenilir ve uzmanlık sahibi olan ve aynı zamanda istenen marka imajı ile uyumlu olan ünlü kişilerin kullanılmasına özen gösterilmektedir (Hakimi vd., 2011). Ünlü kişi ve ürün arasında uyum sağlandığında ünlü kullanımı tüketiciler üzerinde daha etkili olmaktadır (Kahle ve Homer, 1985; Lohneiss ve Hill, 2014; Tingchi Liu vd., 2007).

Ünlü kullanımı, tüketicilerin ünlüyü markayla kolayca ilişkilendirebilmesi, markaların yerel ve uluslararası pazarlarda marka imajını geliştirebilmesi ve markaları rakiplerinden farklılaştırabilmesi nedeniyle pazarlamacılar tarafından etkili bir araç olarak görülmektedir (Roll, 2015). Hakimi ve arkadaşları (2011) tarafından yapılan araştırmaya göre, fiziksel açıdan çekici bir ünlünün kullanımı, bir markanın imajını geliştirebilmekte ve tüketicileri bu markayı satın almaya yönelik olarak teşvik edebilmektedir. Benzer şekilde, Khan (2018) markaların ünlü kullanımından yararlanarak tüketicilerin zihnindeki marka imajlarını geliştirmeyi ve tüketicilerin satın alma niyetini etkilemeyi hedeflediklerini belirtmiştir.

Reklamlarda ünlülerin kullanılmasının, ünlü olmayan oyuncular veya modellerden daha etkili olduğu görülmektedir. Bunun nedeni ünlü kişilerin tüketicilerin zihninde aktif kişiliklere sahip oldukları için canlı bir mesaj taşımalarıdır (McCracken, 1989). Ambroise ve arkadaşları (2014) yaptıkları araştırmada ünlülerin algılanan kişiliğinin markaya transfer edildiğini tespit etmişlerdir. Bu nedenle bu strateji aracılığıyla, hedef kitlenin zihninde güçlü bir marka kişiliği algısı yaratıp sürdürmek amaçlanmaktadır (Kang ve Choi, 2016).

Reklamlarda ünlü kullanımı stratejisi, marka kişiliğinin yanı sıra, tüketicilerle duygusal bağ kurmayı (Erdogan, 1999; McCracken, 1989) ve marka bilinirliği oluşturmayı (Erdogan vd., 2001) amaçlamaktadır. Yapılan araştırmalar reklamlarda ünlü kullanımının marka bilinirliğini ve hatırlamayı desteklediğini göstermektedir (Friedman ve Friedman, 1979). Ayrıca, bu strateji tüketicilerin satın alma niyetlerini (Tripp vd., 1994) ve ürünün algilanan değerini olumlu yönde etkilemektedir (Dean ve Biswas, 2001). Literatürdeki farklı çalışmalar ise ünlü kullanımının pazarlama iletişiminde, ürün imajında, satın alma davranışlarında ve markanın pozitif hatırlanmasında etkili olduğunu kanıtlamaktadır (Mansour, 2016; Seno ve Lukas, 2007; Spry vd., 2011; Till vd., 2008). Thwaites ve arkadaşlarına (2012) göre reklamlarda ünlülerin kullanımı tüketicilerin dikkatini çekmektedir. Bu nedenle bu yöntem tüketicilerin ürün kategorisine yönelik ilgilenimlerinin düşük olduğunda, satın alma kararı almak için mevcut zamanlarının kısıtlı olduğunda, yeni marka tanıtımında veya marka imajının değiştirilmesinde özellikle etkili olabilmektedir. Bununla birlikte farklı mesleklere sahip olan ünlüler, tüketicilerin marka seçim davranışlarını, algılarını, tutumlarını ve niyetlerini etkilemek için kullanılmaktadır (Mishra vd., 2015; Shimp, 2003). Ünlülerin oynadığı reklamlar diğer reklamlarla karşılaştırıldığında, tüketiciler tarafından daha eğlenceli olarak algılanmakta, daha fazla dikkat çekmekte ve ürünün hatırlanmasına yardımcı olmaktadır (Bowman, 2002, ss.14-15). Ulusal ve uluslararası ünlüler tüketicilerin satın alma kararlarını ve yeniden satın alma niyetlerini etkilemektedir (McCormick, 2016). Goldsmith ve arkadaşları (2000) ünlülerin algılanan imajının, ürün seçimi ve satın alma davranışı üzerinde olumlu etkisi olduğunu bulmuşlardır. Ünlü kullanımı tüketicilerin dikkatini artırmakta, reklamları unutulmaz, inandırıcı, cazip hale getirmekte ve ürüne 
cazibe katmaktadır (Spielman ve Hayes, 1981, ss.13-14). Ayrıca, yapılan araştırmalar ünlü seçiminde uygun kriterler kullanıldığında, reklamda ünlü kullanımının, marka farkındalığı yaratılması, satışların artırılması ve farklılaşma yaratılmasında önemli bir rol oynayacağını ortaya koymuştur (Jamil vd., 2014; Mikuláš ve Světlík, 2016). Kaikati (1987) çalışmasında, ünlü kullanımının firmalar için beş avantajının olduğunu tespit etmiştir. Bunlar dikkat çekmek, kriz yönetimi, markanın yeniden konumlandırılması, küresel pazarlama ve satışların artırılması şeklinde ifade edilmiştir.

\section{Reklamlarda Ünlü Kullanımına İlişkin Tüketici Tutumları}

Tutum bir nesne, bir kişi, bir konu veya fikir hakkındaki olumlu, olumsuz veya nötr olma yönündeki değerlendirmelerdir. Bu değerlendirmelere göre bireyler, belirli şekillerde davranma eğilimindedirler. Diğer bir ifadeyle tutum bireyin bir bilgi veya durum hakkında aldığı zihinsel duruşunu, hissini veya duyguyu ifade etmektedir. Tüketicilerin piyasaya yeni çıkan bir ürünü/hizmeti satın alması, eskiden satın aldığı ürünü/hizmeti değiştirmesi, tutum oluşturulması ve tutumun değiştirilmesiyle ilgilidir (Koç, 2016, ss. 291292).

Tutumlar, markaya veya markanın belirli ürünlerine karşı oluşabilmektedir. Spears ve Singh $(2004$, s.55) marka tutumunu, davranışları harekete geçirme olasılığı yüksek olan, markanın kalıcı ve tek boyutlu bir özet değerlendirmesi şeklinde tanımlamıştır. Howcroft ve arkadaşları (2002, s.111) göre ise tutumlar, bireylerin belirli nesnelere karşı olumlu veya olumsuz tepkiler vermesini sağlamaktadır. Bu nedenle tüketici tutumlarını anlamanın yanı sıra tutumları tahmin etmek önemlidir.

Tutumlar bireyleri belirli uyarıcılara karşı tutarlı davranmaya yönelterek herşeyi yeniden yorumlama zahmetinden kurtarmaktadır. Bir ürün veya hizmet hakkında oluşmuş tutumu değiştirmek oldukça zor ve maliyetlidir (Tek ve Özgül, 2013, s.131). Bu nedenle amaçlar doğrultusunda bir tutum oluşturmak oldukça önemlidir. Etkin bir pazarlama stratejisi ile tüketicilerin tutumları ve marka bilinç düzeyleri belirlenmelidir. Böylelikle pazarlama hedeflerine ulaşmak mümkün olabilir. Ayrıca, farklı farkındalık ve tutum dă̆ılımları birbirinden farklı pazarlama stratejilerinin kullanılmasına yol açabilir. Bu nedenle de tutumun belirlenmesi oldukça önemlidir (Twedt, 1967, s.64).

Tutumlar algılama, öğrenme, motivasyon, kişilik ve kültür gibi konularla etkileşim halindedir. Tutumlar geçmişteki deneyimlerden ve içinde bulunulan çevreden öğrenilmektedir (Koç, 2016, ss.291-292). Voss ve arkadaşları (2003, s.319) çalışmalarında tüketicilerin markalara ve ürünlere yönelik tutumlarının oluşumunda ve satın alma niyetlerinin gelişmesinde karmaşık süreçlerin olduğunu belirtmişlerdir. Özellikle hedonik ve faydacı yapıların, ürünlere ve markaya yönelik tutumun önemli boyutlarından olduğu sonucuna ulaşılmıştır. Zarantonello ve Schmitt (2013, s.255) ise marka tutumunun markayı deneyimleme imkanı sunan etkinliklerdeki ilişkiyi yönlendirdiğini ortaya çıkarmıştır.

MacKenzie ve arkadaşları (1986, s.130) yaptıkları çalışmada reklamların marka tutumları ve satın alma niyeti üzerindeki doğrudan veya dolaylı olarak aracı etkisini araştırmışlardır. Bu doğrultuda reklamların marka tutumlarını etkilediği sonucuna ulaşılmıştır. Chung ve Austria (2010, s.581) ise çalışmalarında sosyal medya pazarlama mesajlarına yönelik tutumların, sosyal medya etkileşimi ve bilgi sağlama memnuniyeti ile ilişkili olduğunu ortaya koymuşlardır. De Run ve Ting (2013, s.208) tarafından yapılan çalışmada, reklamlara yönelik tutumun pazarlama öğrencileri ile pazarlama öğrencisi olmayan öğrenciler arasındaki benzerlik ve farklılıkları tespit edilmektedir. Sonuç olarak, pazarlama öğrencilerinin reklama yönelik tutum ve davranışlarının diğerlerinden önemli ölçüde farklı olduğu bulunmuştur.

Bekk ve Spörrle (2010) çalışmasında ünlü bireylerin algılanan kişilik özelliklerinin olumlu tutum oluşturmada etkili olup olmadığını araştırmışlardır. Araştırmalarının sonucunda ünlülerin algılanan kişilik özelliklerinin tüketicilerde olumlu tutum oluşmasında etkili olduğu bulunmuştur. Ong ve Ong (2015) ise yaptıkları 
çalışmada ünlü bireyin güvenilirliğinin, uzmanlığının ve çekiciliğinin satın alma niyeti üzerinde etkisinde, reklamlara yönelik tutumun aracılık etkisi yaptığı sonucuna ulaşmışlardır. Bhatt ve arkadaşları (2013) ise ünlünün kaynak güvenilirliğinin, tüketicilerin reklamlara ve markaya yönelik tutumu üzerinde etkisi olduğunu tespit etmişlerdir. Doss (2011) çalışmasında ünlü bireyin güvenilirliğinin ve uzmanlığının tüketicilerin markalı bir ürüne yönelik tutumunu etkilediği sonucuna ulaşmıştır. Ayrıca, tüketicilerin markaya yönelik tutumlarını ünlü birey ile ilgili tutumlarının etkilediği saptanmıştır.

Son yıllarda gerçekleştirilen araştırmalarda ünlü kullanımının tüketici tutumu üzerinde yüksek seviyede etkiye sahip olduğu görülmektedir. Örneğin, Zhu ve çalışma arkadaşları çalışmalarında Çinli tüketicilerin fonksiyonel bir markanın reklamlarında Çinli bir ünlüyü kullanması durumunda, aynı değere sahip Batılı bir ünlüyü kullanmasına oranla markaya yönelik daha güçlü bir tutuma sahip olduklarını bulmuşlardır (Zhu vd., 2019). Min ve arkadaşlarına (2019) göre reklamda yer alan ünlü ve marka arasında bir bağlantı oluşmakta ve ünlü ile ilgili olumsuz bilgiler ünlü tarafından desteklenen markaya yansıyabilmektedir. Bu araştırma sonuçlarına göre ünlü-marka uyumu ve itibarı, tüketicilerin marka veya ürüne yönelik tutumlarının yanı sıra satın alma niyetlerini de önemli ölçüde etkilemektedir (Min vd., 2019). Yaxuan ve arkadaşları (2020) reklamlarında sadece bir ünlü kullanan markaya yönelik, reklamlarında birden fazla ünlü kullanan markalara oranla tüketicilerin daha güçlü marka tutumuna sahip olduklarını açıklamaktadırlar. Bu bağlamda reklamlarda birden fazla ünlü kullanıma oranla bir ünlü kullanımı, tüketicilerin markayla yönelik bağlantı kurma hissini arttırmakta ve bu da marka yönelik olumlu tutumları güçlendirmektedir (Yaxuan vd., 2020).

\section{Metodoloji}

$\mathrm{Bu}$ araştırmanın temel amacı, 18-35 yaş arasındaki genç tüketicilerin bir ünlünün aynı sektörde ve birbirine rakip olan markaların reklamlarında yer almasına yönelik tutumlarının keşfedilmesidir. Katılımcıların tutumları ünlüye ve ikinci markaya yönelik olarak incelenmiştir. Araştırmada ayrıca katılımcıların ünlüye ve ikinci markaya yönelik tutumları eğitim durumları itibariyle de irdelenmiştir.

Araştırmanın amacı doğrultusunda yanıt aranan araştırma soruları ise aşağıdaki gibidir:

1. Aynı ünlünün farklı zaman dilimlerinde iki rakip markanın reklamında yer alması durumunda genç tüketicilerin ünlüye yönelik tutumları nelerdir?

2. Aynı ünlünün farklı zaman dilimlerinde iki rakip markanın reklamında yer alması durumunda genç tüketicilerin ikinci markaya yönelik tutumları nelerdir?

Çalışmanın örneklemini İstanbul Üniversitesi İşletme Fakültesi lisans ve lisansüstü öğrencileri oluşturmaktadır. Katılımcıların yaş aralığı 18-35 yaş arası olarak belirlenmiştir. Yapılan araştırmalarda, özellikle 18-25 yaş arasındaki genç tüketicilerin, daha ileri yaştaki tüketicilere kıyasla, iletişim çalışmalarında ünlü kullanımını daha fazla hatırladıkları bulunmuştur (Biswas vd., 2009). Kalitatif araştırma kapsamına alınacak örneklemin seçilmesinde, tesadüfi olmayan örnekleme yöntemlerinden biri olan amaçsal örnekleme yöntemi kullanılmıştır. Burada Daymon ve Holloway (2010) kalitatif araştırmacıların amaçsal örnekleme tekniğini seçmelerinin uygun olmasının nedenini kalitatif araştırmaların amacının popülasyona genellemeyi sağlamak değil, belirli bir fenomeni belirli birey gruplarının perspektifinden anlamak olduğunu belirtmişlerdir. Dolayısıyla, amaçsal örnekleme yöntemi, örneklemin belirli bir amaç için seçilmesidir (Alston ve Bowles, 2003).

Çalışmanın amacı doğrultusunda veri ve bilgilerin toplanmasında yüz yüze odak grup görüssmesi yönteminden yararlanılmıştır. Bu yöntemin tercih edilmesinin nedeni ise bir konu hakkındaki yeni fikirlerin, düşüncelerin ve duyguların ortaya çıkarılması, tüketicilerin belirli pazar koşullarındaki davranışlarının nedenlerinin anlaşılması, tüketicilerin katılımına olanak tanınması, geniş kapsamlı katılımcı yanıtlarının ortaya çıarılması ve ulaşılması zor olan bilgi kaynaklarının biraraya getirilmesi yönünde sağladığı avantajlardır (Hair, 2010). 
Bunun yanı sıra, odak grup çalışmaları, geleneksel grup görüşmelerinden daha fazla bilgi işlemesine izin veren bir sinerji sunmakta, katılımcıların etkileşimlerinden bir düşünce ve fikir zinciri yaratmaktadır (Gillham, 2005). Odak grup çalışmasında, (1) odak grup çalışmasının planlanması, (2) odak grup görüşmelerinin organize edilmesi ve (3) sonuçların analiz edilmesi ve raporlanması olmak üzere üç aşama izlenmiştir (Hair, 2010).

Araştırmanın örneklem büyüklüğü 40 kişi olarak belirlenmiş olup bu kapsamda toplam dört adet odak grup görüşmesi gerçekleştirilmiştir. Odak grupların büyüklügü ise 9-12 kişi arasındadır. Odak grup görüşmeleri Mayıs 2018-Haziran 2018 tarihleri arasında gerçekleştirilmiştir. Odak grup görüşmelerinden ikisi lisans öğrencilerinin, biri yüksek lisans öğrencilerinin, biri ise doktora öğrencilerinin katılımıyla yapılmıştır. Odak grup görüşmelerinin süresi 45-60 dakika arası olarak belirlenmiştir. Tüm görüşmelerde, katılımcıların izni alınarak ses kaydı yapılmıştır. Araştırma kapsamında şampuan ve içecek olmak üzere iki farklı sektör için çalışma yapılmıştır. Bu doğrultuda iki ünlü ve dört marka değerlendirilmiştir. Odak grup görüşmelerinde, ilk olarak reklamlarda yer alan ünlüye ilişkin olarak katılımcıların görüşleri alınmıştır. İkinci olarak aynı ünlünün farklı zaman dilimlerinde yer aldığı, iki rakip marka tarafından yayınlanan reklam filmleri katılımcılara izletilmiştir. Son olarak açık uçlu ve yapılandırılmış sorular aracıllğ̆ıla katılımcıların söz konusu ünlüye ve markalara ilişkin düşünceleri keşfedilmeye çalışılmıştır.

Araştırma sonucunda elde edilen veri ve bilgilerin analizinde tematik analiz yönteminden yararlanılmıştır. Tematik analiz, daha geniş temalar haline getirilen deneyimlerin veya fenomenlerin kavramsal anlayışlarını üretmek için toplanan verilerin birimlerini ve kategorilerini sınıflandırmak ya da karşılaştırmak amacıyla kullanan verileri kodlama sürecidir (Butler-Kisber, 2010). Tematik analiz yöntemi, katılımcıların duygularını, algılarını, ilişkilerini tanımlayarak (Bird vd., 2009) görüşlerini ve deneyimlerini ortaya koyabilmesi nedeniyle (Paskins vd., 2010) keşifsel araştırmalar için uygun bir yöntem olarak değerlendirilmektedir (Roper ve Shah, 2007). Bu araştırma kapsamında verilerin analizinde kodlama, sınıflandırma ve sorgulama analizlerinden faydalanılmıştır. Sorgulama analizinde, kelime sıklığı ve kodlama yöntemi kullanılmıştır. Temel veri analizi teorisi kullanılarak üç aşamalı kodlama aracılığıyla nitel veriler analiz edilmiştir. İlk olarak, satır-satır kodlama yöntemiyle, metin konularını, cümleleri, paragraflara ekli konuları ve özellikleri temsil eden teorik kavramlara ayırma amaçlanmıştır (Strauss ve Corbin, 1990). Verilerin analizinde NVivo10 programından yararlanılmıştır.

\section{Bulgular}

Araştırma kapsamında şampuan ve içecek olmak üzere iki farklı sektör için çalışma yapılmıştır. Şampuan ve içecek sektörü için birer ünlü ve ikişer marka değerlendirilmiştir. Odak grup görüşmelerinde öncelikle katılımcıların ünlüye yönelik düşünceleri alınmıştır. Sonrasında ise farklı zamanlarda yayınlanan, iki rakip markaya ait reklamlar gösterilmiştir. Devam eden süreçte açık uçlu sorularla katılımcıların söz konusu ünlüye ve markalara ilişkin düşünceleri keşfedilmeye çalışılmıştır. Araştırma bulgularının analizi sonucunda elde edilen kodlar ve frekanslar incelendiğinde, genç tüketicilerin bir ünlünün aynı sektörde ve birbirine rakip olan iki markanın reklamlarında yer almasına yönelik tutumlarına ilişkin önerilen model Şekil 1'de yer almaktadır. 


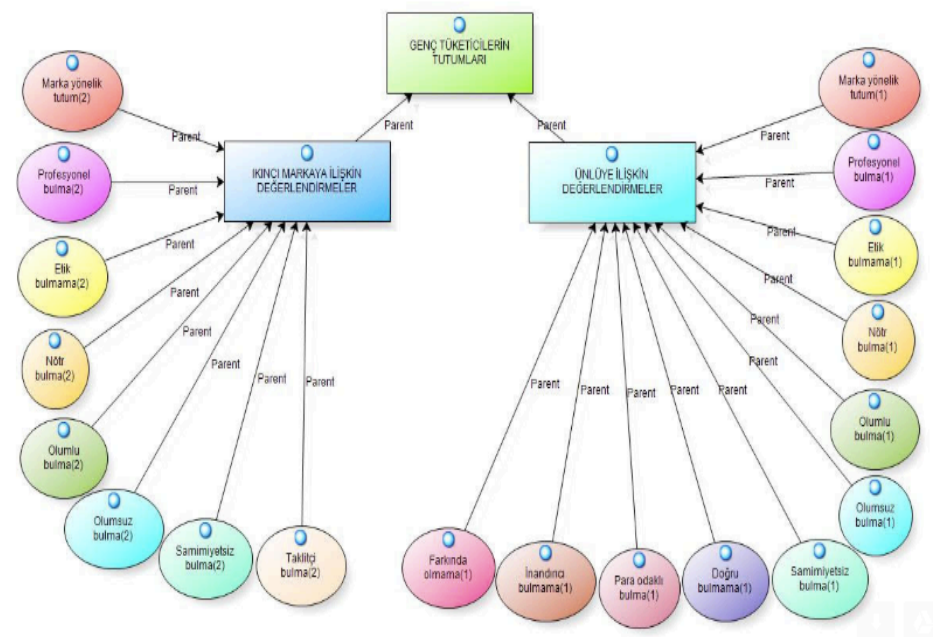

Şekil 1. Araştırmada kurulan ilişkilerin modeldeki görünümü

Şekil 1'de görüldüğü üzere, genç tüketicilerin bir ünlünün farklı zaman dilimlerinde aynı sektörde ve birbirine rakip olan iki markanın reklamlarında yer almasına yönelik tutumlarının (1) ünlüye ilişkin tutumları ve (2) ikinci markaya ilişkin tutumları olmak üzere iki gruba ayrıldığı saptanmıştır. İkinci marka olarak atfedilen ise ünlü kişinin rakip markanın reklamlarında önceki zaman diliminde yer almasına rağmen, aynı ünlü ile kendi reklam çalışmalarına yer veren işletmelerdir.

\section{Katılımcıların Ünlüye İlişkin Tutumları}

Gerçekleştirilen odak grup görüşmelerinde, katılımcılara bir ünlünün, farklı zaman dilimlerinde aynı sektörde ve birbirine rakip olan iki markanın reklamlarında yer alması durumunda ünlüye ilişkin değerlendirmelerinin ne olduğu sorulmuştur. Katılımcıların bu soruya ilişkin olarak verdikleri yanıtlar analiz edilerek elde edilen kodlar ve frekanslar ise Şekil 2'de sunulmaktadır:

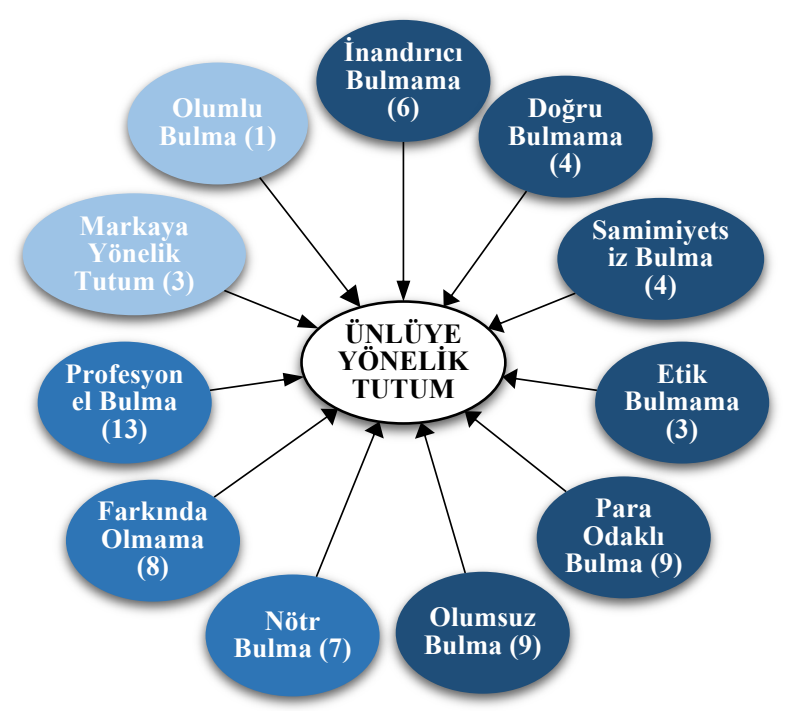

Şekil 2. Katılımcıların aynı sektörde ve birbirine rakip olan iki markanın reklamlarında yer alan ünlüye ilişkin tutumları 
Şekil 2'de görüldüğü gibi, katılımcıların aynı sektörde ve birbirine rakip olan iki markanın reklamında yer alan ünlüye yönelik tutumlarını oluşturan ifadeler, "inandırıcı bulmama", "doğru bulmama", "samimiyetsiz bulma”, "etik bulmama”, "profesyonel bulma”, "para odaklı bulma”, "olumsuz bulma”, "farkında olmama”, "nötr bulma” ve "markaya yönelik tutum” kodları altında toplanmaktadır. Bu kodlar incelendiğinde ise, tüketicilerin tutumlarının olumsuz, nötr ve olumlu olmak üzere üç gruba ayrıldığı görülmektedir.

\section{Katılımcıların ünlüye ilişkin olumsuz tutumları}

Genç tüketicilerin bir ünlünün aynı sektörde ve birbirine rakip olan iki markanın reklamlarında yer almasına yönelik olumsuz yöndeki tutumları, "inandırıcı bulmama”, "doğru bulmama", "samimiyetsiz bulma”, "etik bulmama", "para odaklı bulma" ve "olumsuz bulma" olmak üzere altı kategoride ele alınmıştır.

İlk olarak araştırmaya katılan tüketicilerin değerlendirmeleri incelendiğinde, bir ünlünün aynı sektörde ve birbirine rakip olan iki markanın reklamlarında yer almasının, ünlünün inandırıcılığını olumsuz yönde etkilediğine yönelik ifadeler saptanmıştır. Bu görüşe ilişkin olarak odak grup görüşmelerinde yer alan ifadelerden bazıları aşağıdaki gibidir:

“Ünlü (A) ve Ünlü (B)'nin, iki farklı markanın reklamında oynaması, daha çok bana ünlüye karşı inandırıcılığını etkiliyor olumsuz bir şekilde.” (Odak Grup 1)

"Yarın, öbür gün, üç sene sonra, Ünlü (A) başka bir markayla beraber reklama çıtığı zaman ve bu çok iyidir dediği zaman ben inanmam artık. Yani iyi bir şey değil." (Odak Grup 1)

"Belki etiktir tartışılır ama inandırıcılığını yitirdi." (Odak Grup 1)

İkinci olarak katılımcıların bir kısmı ise aynı sektörde ve birbirine rakip olan iki markanın reklamlarında yer alan bir ünlünün bu davranışını doğru bulmadıklarını belirterek bu durumu olumsuz olarak değerlendirdiklerini ifade etmişlerdir. Katılımcıların bu yöndeki bazı ifadeleri ise aşağıdaki gibidir:

"Sonuçta aynı sektördeki iki markayı yukarıya çıkarmaya çalıştı. Ben bunun doğru olmadığını düşünüyorum kendisi açısından.” (Odak Grup 2)

“Ben Ünlü (A)'nın kendi yaptığını doğru bulmuyorum. Neredeyse ikisine de 'saçları parlak gösterir' diyor ama önce diğerine söylemiş." (Odak Grup 3)

Üçüncü olarak katılımcıların görüşleri, bir ünlünün aynı sektörde ve birbirine rakip olan iki markanın reklamlarında yer almasının, ünlünün verdiği samimiyet duygusunu olumsuz yönde etkilediğini göstermektedir. Bu doğrultuda katılımcıların paylaştığı düşünceler şu şekildedir:

"Yani her türlü bana samimiyetsiz gelirdi. Çünkü hem onu hem bunu savunamazsın sonuçta." (Odak Grup 2)

"Bende samimiyetsizliğe yol açıyor bu durum.” (Odak Grup 3)

"Bence hem birinde oynayıp sonra işte ona geçmesi bir samimiyetsizlik yani hani." (Odak Grup 4)

“Ama bizim algımızda Marka (1) iyiydi de neden Marka (2). de iyi dedin. Samimiyetsizlik oluşturuyor.” (Odak Grup 4)

Dördüncü olarak araştırma kapsamında bir ünlünün aynı sektörde ve birbirine rakip olan iki markanın reklamlarında yer alması durumu katılımcıların bir kısmı tarafından etik bulunmamaktadır. Bu olumsuz görüş çerçevesinde paylaşılan ifadelerden bazıları ise aşağıdaki gibidir:

"Ben etik bulmuyorum açıkçası iki ayrı markada oynamasını." (Odak Grup 4)

“Etik değil." (Odak Grup 4) 
Beşinci olarak katılımcıların, bir ünlünün aynı sektörde ve birbirine rakip olan iki markanın reklamlarında yer almasını ünlünün para odaklı olması şeklinde değerlendirdiği görülmüştür. Bu görüşü şekillendiren ifadelerden bazıları ise aşağıdaki gibidir:

"Yani kim parayı verirse onun markasında oynarım tarzında gibi olmuş bence.... İş ilişkilerinin tamamıla paraya dönük olduğunu hatırlatıyor bana... Ünlü (A) da para almak için Marka (2)'nin teklifini kabul ediyor." (Odak Grup 3)

“Ya o biraz Ünlü (A)'nın kişiliğiyle ilgili. Maşallah yani kim verse, gel o zaman bugün şu reklamda oyna dese demek ki maddi açıdan bakıyor olaylara. Siz hangisine iyi para verirseniz, o da gidip o reklamda oynayacak. X marka da reklamında iyi para verse, gidip orda da oynayacak, biz yine Ünlü (A)'y1 göreceğiz yani.” (Odak Grup 4)

"Ya bu maddi açıdan çok şey geldi. 'Aa ne kadar da maddi açıdan yani oraya gitmiş’ filan. Tabii ki de hoş değil insanların üstünde bu algıyı bırakmaları.” (Odak Grup 4)

Son olarak araştırma kapsamında katılımcıların bir ünlünün aynı sektörde ve birbirine rakip olan iki markanın reklamlarında yer almasını olumsuz olarak değerlendirdikleri görülmüştür. Bu yönde dile getirilen görüşlerden bazıları aşă̆ıdaki gibidir:

"Onu ben bir markayla özdeşleştirdikten sonra, başka bir rakip markaya geçmesi, yine aynı sektörde olan bir ürünle geçmesi olumsuz imaj yaratıyor bende.” (Odak Grup 1)

“Ünlü (A)'nın hem Marka (1)'de hem Marka (2)'de oynaması olumsuz etki yaratabiliyor. Benim için yaratabiliyor.” (Odak Grup 1)

"Çok itici geliyor bana." (Odak Grup 3)

"Ürünü almamda etkili değil ama bir antipati oluşturuyor." (Odak Grup 4)

\section{Katılımcıların ünlüye ilişsin nötr tutumları}

Genç tüketicilerin bir ünlünün aynı sektörde ve birbirine rakip olan iki markanın reklamlarında yer almasına yönelik nötr yöndeki tutumları, "profesyonel bulma", "nötr bulma" ve "farkında olmama" olmak üzere üç kategoride toplanmaktadır.

Öncelikle araştırmaya katılan tüketicilerin görüşleri incelendiğinde, bir ünlünün aynı sektörde ve birbirine rakip olan iki markanın reklamlarında yer alması durumunun, tüketicilerin büyük bir kısmı tarafından profesyonellik olarak algılandığı görülmüştür. Bu kapsamda paylaşılan ifadelerden bazıları aşağıdaki gibidir:

"Hiç bir şey farketmez. Profesyoneldir. Ordan oraya geçmesi hiçbir his oluşturmaz. Gayet normal bir süreç.” (Odak Grup 2)

“Ünlü (A)’nın aynı reklamda oynaması benim satın alma fikrimi değiştirmez. Çünkü profesyonel bir şey. (Odak Grup 3)

“Ünlü (A), Marka (1)'den Marka (2)’ye geçti. Çünkü profesyonellik. Gençken ne kadar para kazanırsam o kadar iyi diyor ki, bence de yani öyle olması lazım. O da rekabet savaşı veriyor baktığımızda." (Odak Grup 3)

"Ben profesyonel olarak düşünürüm.” (Odak Grup 1)

Bunun yanı sıra, araştırma kapsamında katılımcıların bir kısmı ise bir ünlünün aynı sektörde ve birbirine rakip olan iki markanın reklamlarında yer alması durumunun kendilerini etkilemediğini ve düşüncelerinde hiçbir şey oluşturmadığını belirtmiştir. Bu kapsamda dile getirilen bazı görüşler aşağıdaki gibidir: 
"Çok şey yapmadı, zaten benim için şampuanlar arasında çok bir fark olduğunu düşünmüyorum. Buraya geçmesi de bir şey düşündürmedi." (Odak Grup 2)

"İki markaya olan bağlılı̆̆ım ve uzaklı̆̆ım eşit olduğu için bence hiç sorun yok. Olabilir. Şampuanlarda öyle bir marka bağlılığı yaşamadığım için herhangi bir sorun teşkil etmiyor.” (Odak Grup 3)

Diğer yandan tüketicilerin bir ünlünün aynı sektörde ve birbirine rakip olan iki markanın reklamlarında yer almasına yönelik tutumlarını şekillendiren bir başka durum ise, iki reklamın yayınlanma tarihleri arasında uzun zaman olması nedeniyle, ünlünün her iki markanın reklamında oynadığının hatırlanmaması veya farkında olunmamasıdır. Aynı ünlünün yer aldığı şampuan sektörüne ait reklamlar iki yıl, içecek sektörüne ait reklamlar ise beş yıl arayla yayınlanmıştır. Bu durumu ifade eden görüşlerden bazıları aşağıda yer almaktadır:

“Arada yıl farkı olduğu için, ben şu anda Marka (1)'in reklamını görmesem, hiç aklıma gelmezdi. Ünlü (A), Marka (1)'in reklamında da oynamıştı gibi bir şey gelmez.” (Odak Grup 2)

“Çok da böyle şey olmadı bende; Aa bu Ünlü (A) oynadı şurda, o zaman bu Ünlü (A)'nın oynadığı şampuana gidelim gibi bir şey olmadı bende gerçekten. İnanın şu iki reklamı siz gösterene kadar unutmuşum bile. Hem Marka (1)'i hem Marka (2)'yi o kadar da çok görmüşüm ve unutmuşum reklamları.” (Odak Grup 4)

“Çünkü ben Marka (2)'nin reklamını ilk başta billboard'da gördüm ve Ünlü (A)'yı görünce hiç yadırgamadım. “Aa, Marka (2)'in reklamında oynamıștı neden buraya geçti” demedim.” (Odak Grup 3)

\section{Katılımcıların ünlüye ilişkin olumlu tutumları}

Genç tüketicilerin bir ünlünün aynı sektörde ve birbirine rakip olan iki markanın reklamlarında yer almasına yönelik olumlu yöndeki tutumları "markaya yönelik tutum" ve "olumlu bulma" olmak üzere iki kategori altında toplanmaktadır.

Araştırmaya katılan tüketicilerin bir kısmının ise bir ünlünün aynı sektörde ve birbirine rakip olan iki markanın reklamlarında yer alması durumunda, ünlüye ilişkin düşüncelerinin ikinci markaya yönelik tutumlarının değiştiği görülmüştür. Buna istinaden paylaşılan görüşler aşağıdaki gibidir:

“Fakirken zengin olmuş gibi düşünürüm ben.” (Odak Grup 1)

"Popülerleşmiş.” (Odak Grup 3)

"Sosyo-kültürel hali yükseliyor anlamına geliyor. Yani işaret." (Odak Grup 4)

Aynı sektörde ve birbirine rakip olan iki markanın reklamlarında yer alan bir ünlüye ilişkin olumlu tutum içinde olan bir katılımcının görüşü ise aşağıdaki gibidir:

“Ünlü (A)’yı haklı buluyorum. ......etik geliyor” (Odak Grup 3)

\section{Katılımcıların İkinci Markaya ilişsin Tutumları}

Gerçekleştirilen odak grup görüşmelerinde, katılımcılara bir ünlünün, farklı zaman dilimlerinde, aynı sektörde ve birbirine rakip olan iki markanın reklamlarında yer alması durumunda, ikinci markaya ilişkin değerlendirmelerinin ne olduğu sorulmuştur. Katılımcıların bu soruya ilişkin olarak verdikleri yanıtlar analiz edilerek elde edilen kodlar ve frekanslar ise Şekil 3'de sunulmaktadır. 


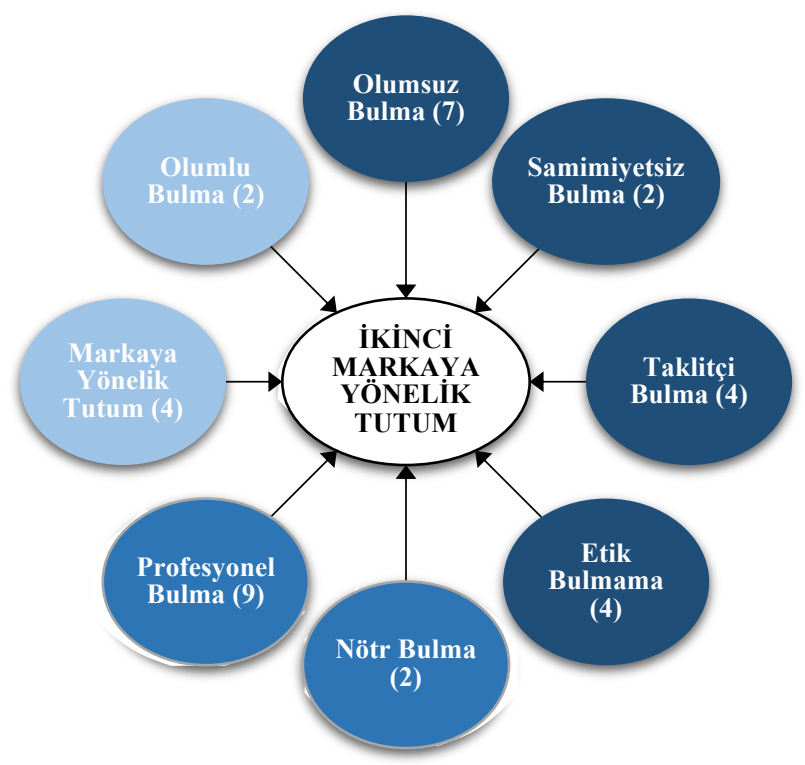

Şekil 3. Katılımcıların ikinci markaya ilişkin tutumları

Şekil 3'de görüldügü gibi, aynı sektörde ve kendisine rakip olan bir markanın reklamında yer alan bir ünlüye, kendi reklamlarında yer veren ikinci bir markaya yönelik tüketici tutumlarını içeren ifadeler, "olumsuz bulma", "taklitçi bulma", "samimiyetsiz bulma", "etik bulmama", "profesyonel bulma", "nötr bulma", "markaya yönelik tutum" ve "olumlu bulma" kodları altında toplanmaktadır. Bu kodlar incelendiğinde ise, tüketicilerin tutumlarının olumsuz, nötr ve olumlu olmak üzere üç gruba ayırmak mümkündür.

\section{Katılımcıların ikinci markaya ilişkin olumsuz tutumları}

Genç tüketicilerin ikinci markaya yönelik olumsuz yöndeki tutumları, "olumsuz bulma”, "samimiyetsiz bulma", "etik bulmama" ve "taklitçi bulma" olmak üzere dört kategoride toplanmaktadır.

İlk olarak araştırmaya katılan tüketicilerin büyük bir kısmının ikinci markaya yönelik olan düşüncelerinin olumsuz yönde olduğu görülmüştür. Bu doğrultuda paylaşılan görüşlerden bazıları aşağıdaki gibidir:

“Marka (2)'nin yaptığı hamle bana çok basit geldi. Hani elimizden başka bir şey gelmiyor gibi. Aynı reklamı başka bir ünlüyle de çekebilirdi.” (Odak Grup 2)

"Kim kimi çalıyorsa, o markanın imajı düşerdi tüketim malzemesiyse bu. Güçlü bir marka bile olsa imajı düşerdi ......Marka algısı segmentine göre zedelenirdi." (Odak Grup 2)

"Ben Marka (2)'nin yöneticisi olsam, reklam ajansı böyle bir teklifle gelse, o reklam ajansıyla çalışmayı bırakırdım. Aynı tarz ürünlerde aynı ünlülerin kesinlikle kullanılmaması gerektiğini düşünüyorum.” (Odak Grup 3)

İkinci olarak katılımcıların bir kısmı ikinci markayı samimiyetsiz bulduklarını belirterek olumsuz yönde görüş belirtmişlerdir. Bu doğrultuda paylaşllan görüşler aşağıdaki gibidir:

"Bende samimiyetsizliğe yol açıyor bu durum, iş ilişkilerinin tamamıyla paraya dönük olduğunu hatırlatıyor bana. Bence Marka (2) samimiyetsiz. Üründen tamamıyla sadece üründen faydalanmak için onu oynatıor." (Odak Grup 3)

“Marka (2) daha samimiyetsiz bence şu an.” (Odak Grup 2)

Üçüncü olarak araştırmaya katılan tüketiciler ikinci markayı taklitçi bulduklarını belirterek bu duruma ilişkin olumsuz bir tutuma sahip olduklarını belirtmişlerdir. Bu yönde iletilen görüşler ise şu şekildedir: 
"Bence marka daha özgün olmalı. Ama başkasının marka yüzünü kullandığı zaman özgün gelmiyor bana. Daha taklit geliyor, o yüzden olumsuz bence.” (Odak Grup 2)

“Herhalde hani Marka (1) de işe yaradığını düşünüyor Ünlü (A)’nın. Muhtemelen o amaçla da kendileri kullandılar." (Odak Grup 2)

Son olarak katılımcıların bir kısmı ise iki markayı etik bulmadıklarını belirterek olumsuz yönde tutumları olduğunu göstermiştir. Bu kapsamda belirtilen görüşlerden bazıları ise şöyledir:

"Oynadığı markanın da bence etik bir karar verdiğini düşünmüyorum pazarlamacısının. Çünkü neden yani, Marka (1)'de çok taze bir yüzken neden diğeri Marka (2) o ünlüyü alsın. Bu etik değildir.” (Odak Grup 4)

\section{Katılımcıların ikinci markaya ilişkin nötr tutumları}

Tüketicilerin ikinci markaya yönelik nötr tutumları, "nötr bulma” ve "profesyonel bulma" olmak üzere iki kategoride toplanmaktadır.

Katılımcıların bir kısmı ikinciye markaya ilişkin görüşlerinin değişmediğini belirterek nötr tutumda olduklarını belirtmişlerdir. Bu yönde ifade edilen bir düşünce aşağıda yer almaktadır:

"Markalar bunu yapabilir bence. Markalara karşı olan görüşüm değişmezdi.” (Odak Grup 3)

Ayrıca, katılımcıların büyük çoğunluğu ikinci markanın hamlesini profesyonel bulduklarını dile getirerek aşağıdaki görüşleri belirtmişlerdir:

"Bence daha iyi bi şey yapıyor. Hem dikkat çekiyor. Orada kendini patlatmış oluyor. Pazarlama yani çıkarına olan bir şey. Şu an rekabet savaşı ortamı. Yapsın bence de.” (Odak Grup 3)

"Bunu profesyonel bir hamle olarak görüyorum." (Odak Grup 3)

\section{Katılımcıların ikinci markaya ilişkin olumlu tutumları}

Tüketicilerin ikinci markaya yönelik olumlu tutumları, "olumlu bulma” ve "markaya yönelik tutum" olmak üzere iki kategoride toplanmaktadır.

Genç tüketicilerin küçük bir kısmı ikinci markaya yönelik olumlu yönde düşündüklerini belirterek aşağıdaki görüşlerini dile getirmiştir:

"Yani olumlu yaklaşıyorum açıkçası." (Odak Grup 2)

"Ben firmalar açısından da etik buluyorum aslında. Çünkü en çok başarılı bir oyuncu, sevilen bir oyuncu, herkes tarafından bilinen bir oyuncu, algı değiştirmeye çalışıyor. Marka (2) sadece ... özelliğini değil başka yönleri de vurgulamaya çalışıyor. İşte bu bunu yapmak için de en üst seviyedeki bir oyuncu veya şarkıcı onu kullanması normal bence yani aslında. Daha çok işine yarar.” (Odak Grup 3)

"Olumlu, çıkarına uygun bir şekilde olabilir. İstersem onun reklam yüzünü alıp oynatırım. Gücünü gösteriyor bence. Ertesi günü bile olsa süre açısından oynatırım. Rakibi çağrıştırır ama doğal olarak. Sadece, oradaydı şimdi buraya geçti şeklinde. Profesyonel olarak markaların bunu yapmasını doğru buluyorum açıkçası." (Odak Grup 2)

Son olarak kimi katılımcıların ikinci markaya yönelik tutumları ise aşağıdaki gibidir:

“Neden Marka (2)'nin böyle bir şey yaptığına anlam veremedim.” (Odak Grup 2)

"Daha kalitesiz bir marka özendiği için kalitelinin reklam yüzünü kullansa, bunun daha az negatif olduğunu düşünüyorum. Ama güçlü bir marka daha güçsüz bir markanın yüzünü kullansa benim o zaman güçlü markayla ilgili algım daha aşağıya çekilebilirdi. Daha negatif düşünürdüm. Güçsüz markayı yükselmeye çalışıyor olarak değerlendirirdim. Ama zaten güçlü bir markanın kendinden güçsüz 
rakibinin reklam yüzünü kullanması daha itici gelirdi. Daha hani gereksiz gibi. Niye böyle bir şey yaptı ki gibi. Ama bunda çok yll olduğu için hiç öyle bir şey düşünmedim.” (Odak Grup 2)

\section{Katılımcıların Tutumlarının Eğitim Seviyelerine Göre Değerlendirilmesi}

Çalışma amacı doğrultusundan gerçekleştirilen odak grup görüşmelerinde, katılımcılara bir ünlünün, farklı zaman dilimlerinde, aynı sektörde ve birbirine rakip olan iki markanın reklamlarında yer alması durumunda ünlüye ve ikinci markaya ilişkin değerlendirmelerinin ne olduğu sorulmuştur. Katılımcıların bu sorulara verdikleri cevaplar eğitim seviyelerine göre değerlendirilmiştir. Çalışmanın amacı doğrultusunda yapılan analizlerden elde edilen kodların katılımcıların eğitim durumuna göre frekansları aşağıda yer almaktadır.

\section{Katılımcıların eğitim durumuna göre ünlüye yönelik tutumlarının değerlendirilmesi}

Katılımcıların ünlüye yönelik tutumları eğitim durumuna göre sınıflandırılarak Tablo 1'de verilmiştir.

Tablo 1

Katılımcıların Eğitim Durumuna Göre Ünlüye İlişkin Tutumlarının Değerlendirilmesi

\begin{tabular}{lccc}
\hline & $\begin{array}{c}\text { Lisans } \\
\text { Öğrencileri }\end{array}$ & $\begin{array}{c}\text { Yüksek Lisans } \\
\text { Öğrencileri }\end{array}$ & $\begin{array}{c}\text { Doktora } \\
\text { Öğrencileri }\end{array}$ \\
\hline İnandırıcı Bulmama & $34 \%$ & $67 \%$ & - \\
\hline Doğru Bulmama & $25 \%$ & $75 \%$ & $50 \%$ \\
\hline Samimiyetsiz Bulma & $50 \%$ & - & $34 \%$ \\
\hline Etik Bulmama & $33 \%$ & $33 \%$ & - \\
\hline Profesyonel Bulma & $77 \%$ & $33 \%$ & $45 \%$ \\
\hline Para Odaklı Bulma & $33 \%$ & $22 \%$ & $12 \%$ \\
\hline Olumsuz Bulma & $44 \%$ & $44 \%$ & - \\
\hline Nötr Bulma & $100 \%$ & - & $28 \%$ \\
\hline Farkında Olmama & $57 \%$ & $15 \%$ & $25 \%$ \\
\hline $\begin{array}{l}\text { Marka Değerine Göre } \\
\text { Değerlendirme }\end{array}$ & $50 \%$ & $25 \%$ & \\
\hline
\end{tabular}

Bu doğrultuda ünlüye yönelik tutumlarda inandırıcı bulmayanların \%67’si; doğru bulmayanların ise \%75’i yüksek lisans öğrencileridir. Samimiyetsiz bulanların \%50'si lisans ve \%50'si doktora öğrencilerinden oluşmaktadır. Etik bulmayanların eğitim seviyelerine göre benzer oranlara sahip olduğu görülmektedir. Profesyonel bulanların \%77'si lisans öğrencilerden oluşmakta ve para odaklı bulanların \%45’i doktora öğrencilerinden oluşmaktadır. Olumsuz bulanların \%44’ü lisans ve \%44'ü yüksek lisans öğrencileri iken nötr bulanların tamamı lisans öğrencileridir. Farkında olmayanların \%57'si lisans öğrencilerinden; marka değerine göre değerlendirme yapanların \%75’i lisans öğrencilerinden oluşmaktadır.

\section{Katılımcıların eğitim durumuna göre ikinci markaya yönelik tutumlarının değerlendirilmesi}

Katılımcıların ikinci markaya yönelik tutumlarının değerlendirilmesi eğitim durumuna göre sınıflandırılarak Tablo 2'de verilmiştir. 
Tablo 2

Katılımcıların Eğitim Durumuna Göre İkinci Markaya İlişkin Tutumlarının Değerlendirilmesi

\begin{tabular}{lccc}
\hline & Lisans Öğrencileri & $\begin{array}{c}\text { Yüksek Lisans } \\
\text { Öğgencileri }\end{array}$ & $\begin{array}{c}\text { Doktora } \\
\text { Öğrencileri }\end{array}$ \\
\hline Samimiyetsiz Bulma & $100 \%$ & - & - \\
\hline Etik Bulmama & $25 \%$ & - & $75 \%$ \\
\hline Profesyonel Bulma & $100 \%$ & - & - \\
\hline Olumsuz Bulma & $71 \%$ & $14 \%$ & - \\
\hline Nötr Bulma & $100 \%$ & - & - \\
\hline $\begin{array}{l}\text { Marka Değerine Göre } \\
\text { Değerlendirme }\end{array}$ & $75 \%$ & $25 \%$ & - \\
\hline Taklitçi Bulma & $100 \%$ & - & - \\
\hline Olumlu Bulma & $100 \%$ & - & - \\
\hline
\end{tabular}

İkinci markaya yönelik tutumun eğitim seviyelerine göre değerlendirilmesinde ise samimiyetsiz bulanların, profesyonel bulanların, nötr bulanların, taklitçi bulanların ve olumlu bulanların tamamı lisans öğrencilerinden oluşmaktadır. Etik bulmayanların \%75’i doktora öğrencileri iken \%25’i lisans öğrencilerdir. Olumsuz bulanların \%71’i ve marka değerine göre değerlendirenlerin \%75’i ise lisans öğrencilerinden oluşmaktadır.

\section{Sonuç ve Öneriler}

Reklamlarda ünlü bireylere yer verilmesi günümüzde oldukça popüler bir yöntemdir. Reklamlarda ünlü bireylere yer verilmesinin tüketici marka veya reklam tutumu oluşturulmasında etkilerinin olduğu bilinmektedir (Lafferty ve Goldsmith, 1999; Pradhan vd., 2016; Zhu vd., 2019). Solomon (2014) araştırmas1 ünlülerin, ürün ve hizmet onaylayıcısı olarak iletilen mesajların önemini ve reklamlarda ünlü kullanımının tüketicilerin markaya karşı tutumlarının ve algılarının şekilendirmesinde veya değiştirmesine oldukça etkili olduğunu açıklamaktadır. Literatürde, ünlü-marka uyumunun tüketicilerin markaya yönelik tutumlarını olumlu etkilediğini inceleyen çalışmaların (Eisend ve Langner, 2010; Min vd., 2019; Munnukka vd., 2016; Zhou ve Whitla, 2013) yanı sıra markaların reklamlarında tek bir ünlü kullanmalarının çok sayıda ünlü kullanmalarına oranla tüketicilerin markaya yönelik daha olumlu tutum geliştirmelerini sağladıklarını inceleyen çalışmalar da yer almaktadır (Yaxuan vd., 2020).

Ancak, ünlü kişinin rakip firma reklamlarında yer almasının etkileri hakkında literatürde çalışma bulunmamaktadır. Oysa günümüzde aynı ünlünün rakip firma reklamlarında yer almasıyla oldukça sık karşılaşılmaktadır. Bu çalışma literatürdeki bu yöndeki eksikliği tamamlaması amacıyla önem arz etmektedir. $\mathrm{Bu}$ çalışma ile ünlü bir kişinin rakip firma reklamlarında yer almasına yönelik tüketicilerin tutumları araştırılmaktadır. Çalışmanın amacı ünlü bir kişinin rakip firma reklamlarında yer alması durumunda bireylerin ünlü kişiye ve ikinci markaya ilişkin tutumlarında ne gibi değişiklikler söz konusu olduğunu araştırmaktır.

Bu çalışma kapsamında odak grup çalışmasından yararlanılmıştır. Yapılan odak grup çalışmaları sonucunda, bireylerin bu durum karşısında farklı tutumlara sahip olduğu bulunmuştur. Bu sonuçlar ünlüye ilişkin tutumlar ve ikinci markaya ilişkin tutumlar olmak üzere iki boyutta ele alınmıştır. Bu iki boyuta da getirilen yorumlar birbirinden oldukça farklıdır. Ünlüye ilişkin tutumlarda, ünlülerin reklamlarında yer aldığ 1 
markaların marka değeri ile ilişkili olarak görüş ayrılıkları ortaya çıkmaktadır. Rakip firma reklamında yer aldığı markanın değeri daha yüksek ise bu durum ünlü ve marka açısından normal karşılanmaktadır. Ünlünün kendisini geliştirdiği düşünülmektedir. Rakip firma için ise eğer güçlü bir marka değerine sahipse nötr olarak değerlendirilmektedir. Düşük bir marka değerine sahip olduğu durumlarda diğer marka yüzünü kullanarak, kendi konumunu bu yöntemle iyileştirmeye çalıştığı algısı bulunmaktadır. Tüketiciler marka değerine göre değişken tutum sergilemektedir.

Ünlüye ilişkin tutumları üç kategoride ele almak mümkündür. İlk kategoride bu durumun ünlü hakkında negatif tutumlara yol açtığı, ünlünün samimiyetsiz davrandığı, inandırıcılığının zedelendiği ve bu davranışın doğru olmayıp etik dışı olarak algılandığı şeklindedir. Ünlülerin para odaklı olmaları nedeniyle herşeyi yapabileceklerinin göstergesi olarak görülmektedir. İkinci kategoride bu durumu olumlu ve profesyonel bulan bireyler yer almaktadır. Bu kategoridekiler bunu ünlünün mesleğinin bir gereği olarak görmekte ve normal karşılamaktadırlar. Üçüncü kategoride ise rakip firma reklamlarında yer almasını nötr olarak karşılayan ve bu durumun hiç farkında olmayan bireyler yer almaktadır. Ünlüye yönelik tutumların ilk kategorisinde olumsuz olarak ele alınan yorumlar bulunmaktadır. Ünlüyü inandırıcı bulmama, doğru bulmama, samimiyetsiz bulma, etik bulmama, para odaklı bulma ve olumsuz bulma ifadeleri bu kısımda yer almaktadır. İkinci kategori ünlü bireyin bu davranışını mesleğinden dolayı nötr bulma, farkında olmama ve profesyonel bulma ifadelerinden oluşmaktadır. Üçüncü kategoride ise ünlü bireyin rakip firma reklamlarında yer almasını olumlu bulma ve marka değerine göre değişken değerlendirmeler yer almaktadır.

Odak grup çalışmaları sonrasında ikinci markaya ilişkin tutumları da üç kategoride ele almak mümkündür. İlk kategoride rekabet ortamında olunduğundan aynı ünlünün rakip iki marka reklamlarında yer alması profesyonel değerlendirilmekte ve olumlu bir yaklaşım olarak görülmektedir. İkinci kategoride bu durum nötr olarak ele alınmaktadır. Üçüncü kategoride ise olumsuz olan değerlendirmeler bulunmaktadır. Markanın taklit edici bir yol izlediği, samimiyetsiz davrandığı ve etik dışı bir davranış gerçekleştirdiği düşünülmektedir. Markaya yönelik tutumların ilk kategorisinde olumsuz ifadeler yer almaktadır. Rakip firma olarak adlandırılan firmanın reklam yüzü ile çalışan bu markayı olumsuz bulma, samimiyetsiz bulma, taklitçi bulma ve etik bulmama yorumları ilk kategoride yer almaktadır. Markanın bu hamlesini nötr bulma, profesyonel bulma ve marka değerine göre değişken değerlendirmeler ise ikinci kategoride yer almaktadır. Üçüncü kategoride ise olumlu değerlendirmeler yer almakta ancak bu durumu olumlu bulan az sayıda görüş bulunmaktadır.

Ayrıca, çalışmada katılımcıların ünlüye ve ikinci markaya yönelik tutumları eğitim durumlarına göre değerlendirilmiştir. $\mathrm{Bu}$ bağlamda, ünlüye yönelik tutumlarda inandırıcı bulmayanların ve doğru bulmayanların büyük çoğunluğu yüksek lisans öğrencileridir. Ünlüyü samimiyetsiz bulanların çoğunluğu lisans öğrencilerinden oluşmakta ve etik bulmayanların ise eğitim seviyelerine göre benzer oranlara sahip olduğu görülmektedir. Profesyonel bulanların çoğunluğu lisans öğrencilerden oluşmakta ve para odaklı bulanların çoğunluğu ise doktora öğrencilerinden oluşmaktadır. Olumsuz bulanlar lisans ve yüksek lisans öğrencileri iken nötr bulanların tamamı lisans öğrencileridir. Farkında olmayanların ve marka değerine göre değerlendirme yapanların çoğunluğu lisans öğrencilerinden oluşmaktadır. İkinci markaya yönelik tutumun eğitim seviyelerine göre değerlendirilmesinde ise samimiyetsiz bulanların, profesyonel bulanların, nötr bulanların, taklitçi bulanların ve olumlu bulanların tamamı lisans öğrencilerinden oluşmaktadır. Etik bulmayanların çoğunluğu doktora öğrencileri iken olumsuz bulanların ve marka değerine göre değerlendirenlerin çoğunluğu lisans öğrencilerinden oluşmaktadır.

Pazarlama faaliyetlerin amacı tüketici istek ve ihtiyaçlarına zamanında ve doğru bir biçimde cevap verebilmektir. Tutundurma faliyetleri de işletmelerin tüketiciler ile iletişim kurmak amacıyla gerçekleştirdikleri çalışmalardır. Tüketicilerde olumlu tutum oluşturmak ve tüketicilerin tutumlarını pozitif yönde şekillendirmek amacıyla ünlü kişilerden yararlanılmaktadır. Ancak araştırmanın bulguları doğrultusunda aynı ünlü kişinin rakip firma reklamlarında yer alması tüketici tutumunu genellikle negatif 
yönde etkilemektedir. Böylelikle amaçlanan pazarlama çabalarının tam tersi yönünde hareket edilmektedir. Bu nedenle firmaların markalarının reklamlarında kullanacakları ünlü tercihlerinde bu duruma dikkat etmeleri gerekmektedir. Ayrıca firmaların markalarının reklam yüzlerini belirlerken daha ayrıntılı bir çalışma gerçekleştirmeleri gerekmektedir. Bu kapsamda başarılı bir ünlü kullanımı için reklam verenlerin sadece doğru ünlüyü seçmeleri yeterli olmayıp sunulan mesajı doğru seçmeleri tüketicilerin zihninde kalıcı bir izlenim yaratacaktır. Ayrıca, tüketicilerin mesajı inandırıcı ve güvenilir bulmaları da oldukça önemlidir. Araştırmanın bulgularına göre aynı ünlünün iki rakip firmanın reklamında yer alması tüketicilere inandırıcı gelmemekte ve tüketicilerin güvenlerini zedelemektedir. Pazarlama stratejileri belirlenirken bu duruma dikkat edilmelidir.

Literatür incelendiğinde ünlülerin genel halkın yaşam tarzı ve zihniyetleri üzerinde karizmatik etkileri olduğu görülmektedir. Reklamcılı̆̆ın, marka hatırlanırlığı ve genel marka gücünü artırmak için yardımcı olduğu bilinmektedir (Munnukka vd., 2016). McCormick (2016) çalışmasında alıcıların satın alma niyetinin, sevdikleri ünlülerden önemli ölçüde etkilendiği sonucuna varmıştır. Ünlü kulanımının, ünlü olmayan kaynaklarla karşılaştırıldığında, genel tüketici satın alma davranışı üzerinde olumlu bir etkisi olduğu görülmektedir (Adnan vd., 2017, s.368; Roy vd., 2015, s.148). Bu nedenle, reklam veren markaların ünlü seçerken her zaman çok dikkatli olmaları gerektiği belirtilmektedir. Üstelik doğru seçim hem kısa hem de uzun vadede tüketici zihninde ve yaşam tarzlarında olumlu etkiler yaratmada farklılık yaratabilir. Aynı ünlünün iki rakip firma reklamında yer alması tüketici satın alma kararlarını olumsuz etkiliyebilir. Gelecekteki çalışmalarda, aynı ünlünün rakip marka reklamlarında oynamasının tüketicilerin satın alma davranışı üzerindeki etkileri incelenebilir.

$\mathrm{Bu}$ araştırmanın zaman ve maliyet açısından bazı kısıtları bulunmaktadır. İlk olarak çalışma analizinde yararlanılan odak grup çalışmalarında sadece 40 kişiye ulaşılmıştır. Farklı tüketici grupları üzerinde farklı analiz yöntemleri kullanılarak çalışma konusu derinleştirilebilir. Bir diğeri çalışmada sadece nitel veri toplama yöntemlerinden odak grup kullanmaktadır. Nitel veri toplama yöntemlerinden birkaçı beraber kullanılarak çalışma detaylandırılabilir. Son olarak ise çalışma sadece genç tüketicilerin tutumlarını incelemektedir. Gelecekteki çalışmalar ile farklı yaş gruplarındaki tüketicilerin tutumları incelenebilir ve bu yaş grupları arasında konuya ilişkin farklı tutumların olup olmadığı çalışılabilir.

\section{Kaynakça}

Adnan, A., Jan, F. A., \& Alam, W. (2017). Relationship between Celebrity Endorsements \& Consumer Purchase Intention. Abasyn University Journal of Social Sciences, 10(2), 356-372. http://Ajss.Abasyn.Edu.Pk/Article?Paperid=198

Alston, M and Bowles, W. (2003). Research for Social Workers: An Introduction for Methods 2nd Edition. New York: Oxford University Press

Ambroise, L., Pantin-Sohier, G., Valette-Florence, P., \& Albert, N. (2014). From endorsement to velebrity cobranding: Personality transfer. Journal of Brand Management, 21(4), 273-285. doi:10.1057/Bm.2014.7

Austin, E. W., Vord, R. V. d., Pinkleton, B. E., \& Epstein, E. (2008). Celebrity endorsements and their potential to motivate young voters. Mass Communication and Society, 11(4), 420-436. doi:10.1080/15205430701866600

Bafna, A., Gandhi, P., Jain, A., Dantara, V., Desai, K., Dholakiya, M., Gumani, N., Gagnani, P., Udhani, D., Keswani, K. \& Kanabar, H. (2016). Influence of Celebrity Endorsements on the Consumer Behavior for Facial Care Product. Imperial Journal of Interdisciplinary Research, 2(5), 219-235. https://www.onlinejournal.in// 
Balakrishnan, L., \& Kumar, C. S. (2011). Effect of Celebrity Based Advertisements on the Purchase Attitude of Consumers towards Durable Products (A study with reference to the city of Chennai). World Review of Business Research, 1(2), 98-112. https://www.semanticscholar.org/paper/Effect-of-Celebrity-BasedAdvertisements-on-the-of-Balakrishnan/1f25538c4e1625f2da3a6a9676703f764ffc8de3?p2df

Bekk, M., \& Spörrle, M. (2010). The influence of perceived personality characteristics on positive attitude towards and suitability of a celebrity as a marketing campaign endorser. The Open Psychology Journal, 3(1). doi:10.2174/1874350101003010054

Bhatt, N., Jayswal, R. M., \& Patel, J. D. (2013). Impact of celebrity endorser's source credibility on attitude towards advertisements and brands. South Asian Journal of Management, 20(4), 74-95. https://www.researchgate.net/profile/Jayesh_Patel20/publication/283299097_Impact_of_Celebrity_En dorser's_Source_Credibility_on_Attitude_Towards_Advertisements_and_Brands/links/57f22e5108ae 8da3ce4ed49e/Impact-of-Celebrity-Endorsers-Source-Credibility-on-Attitude-TowardsAdvertisements-and-Brands.pdf

Bird, S., Wiles, J. L., Okalik, L., Kilabuk, J., \& Egeland, G. M. (2009). Methodological consideration of story telling in qualitative research involving Indigenous Peoples. Global Health Promotion, 16(4), 16-26. doi: $10.1177 / 1757975909348111$

Biswas, S., Hussain, M., \& O'Donnell, K. (2009). Celebrity endorsements in advertisements and consumer perceptions: A cross-cultural study. Journal of Global Marketing, 22(2), 121-137. doi: $10.1080 / 08911760902765940$

Bower, A. B., \& Landreth, S. (2001). Is beauty best? Highly versus normally attractive models in advertising. Journal of Advertising, 30(1), 1-12. doi:10.1080/00913367.2001.10673627

Bowman, J. (2002). Facing advertising reality. Media Asia, 7(26), 14-15.

Butler-Kisber, L. (2010). Qualitative inquiry: Thematic, narrative and arts-informed perspectives. Thousand Oaks, CA: Sage. doi:10.41.35/9781526435408

Byberg, A., Hansen, J., \& Basic, M. (2015). Celebrity Endorsement's Impact on Brand Image and Sales: A Case Study on Volvo Cars Sweden. https://www.diva-portal.org/smash/get/diva2:812912/FULLTEXT01.pdf

Carroll, A. (2009). Brand communications in fashion categories using celebrity endorsement. Journal of Brand Management, 17(2), 146-158. doi:10.1057/bm.2008.42

Chung, C., \& Austria, K. (2010). Social Media Gratification and Attitude toward Social Media Marketing Messages: A Study of the Effect of Social Media Marketing Messages on Online Shopping Value. Proceedings of the Northeast Business \& Economics Association, 581-586. https://web.b.ebscohost.com/abstract?direct=true\&profile=ehost\&scope=site\&authtype=crawler\&jrnl $=1936203 X \& A N=56100920 \& \mathrm{~h}=\% 2 b 9$ QpIFVR78SgwHLgsczDa\%2bP9XrdZV7WL2eMQ5iw6dloqLWj BrLr1AJojyRNegHuuUB6TnPALtwBpVNIgjQCQvA\%3d\%3d\&crl=c\&resultNs=AdminWebAuth\&res ultLocal=ErrCrlNotAuth\&crlhashurl=login.aspx\%3fdirect\%3dtrue\%26profile\%3dehost\%26scope\%3ds ite\%26authtype\%3dcrawler\%26jrnl\%3d1936203X\%26AN\%3d56100920

Daymon, C., \& Holloway, I. (2010). Qualitative research methods in public relations and marketing communications. London: Routledge.

Dean, D. H., \& Biswas, A. (2001). Third-party organization endorsement of products: An advertising cue affecting consumer prepurchase evaluation of goods and services. Journal of Advertising, 30(4), 41-57. doi:10.1080/00913367.2001.10673650 
De Run, E. C., \& Ting, H. (2013). Attitude of marketing and non-marketing students towards advertising. Paper presented at the Global Conference on Business, Economics and Social Sciences, Kuala Lumpur. https://www.researchgate.net/publication/256115589_Attitude_of_Marketing_and_Nonmarketing_Students_towards_Advertising

Doss, S. (2011). The transference of brand attitude: the effect on the celebrity endorser. Journal of Management and Marketing Research, 7, 1-11. https://ieeexplore.ieee.org/document/5979012

Eisend, M., \& T. Langner. (2010). Immediate and delayed advertising effects of celebrity endorsers' attractiveness and expertise. International Journal of Advertising, 29(4), 527-46. doi:10.2501/S0265048710201336

Erdogan, B. Z. (1999). Celebrity endorsement: A literature review. Journal of Marketing Management, 15(4), 291-314. doi:10.1362/026725799784870379

Erdogan, B. Z., Baker, M. J., ve Tagg, S. (2001). Selecting celebrity endorsers: The practitioner's perspective. Journal of Advertising Research, 41(3), 39-48. doi:10.2501/JAR-41-3-39-48

Friedman, H. H., ve Friedman, L. (1979). Endorser effectiveness by product type. Journal of Advertising Research, 63-71. https://psycnet.apa.org/record/1981-04308-001

Gillham, B. (2005). Research Interviewing: The range of techniques: A practical guide: McGraw-Hill Education (UK).

Goldsmith, R. E., Lafferty, B. A., \& Newell, S. J. (2000). The impact of corporate credibility and celebrity credibility on consumer reaction to advertisements and brands. Journal of Advertising, 29(3), 43-54. doi:10.1080/00913367.2000.10673616

Hair, J., Wolfinbarger, M., Ortinau, D., \& Bush, R. (2010). Essentials of marketing research. New York, NY: McGraw-Hill Irwin.

Hakimi, B. Y., Abedniya, A., \& Zaeim, M. N. (2011). Investigate the impact of celebrity endorsement on brand image. European Journal of Scientific Research, 58(1), 116-132. https://www.researchgate.net/publication/285721869_Investigate_the_impact_of_celebrity_endorsem ent_on_brand_image

Howcroft, B., Hamilton, R., \& Hewer, P. (2002). Consumer attitude and the usage and adoption of home-based banking in the United Kingdom. International Journal of Bank Marketing, 20(3), 111-121. doi:10.1108/02652320210424205

Hung, K. (2014). Why celebrity sells: A dual entertainment path model of brand endorsement. Journal of Advertising, 43(2), 155-166. doi:10.1080/00913367.2013.838720

Ilicic, J., \& Webster, C. M. (2013). Celebrity co-branding partners as irrelevant brand information in advertisements. Journal of Business Research, 66(7), 941-947. doi:10.1016/j.jbusres.2011.12.014

Jamil, R. A., \& Rameez ul Hassan, S. (2014). Influence of celebrity endorsement on consumer purchase intention for existing products: a comparative study. Journal of Management Info, 4(1), 1-23. doi:10.31580/jmi.v4i1.18

Kahle, L. R., \& Homer, P. M. (1985). Physical attractiveness of the celebrity endorser: A social adaptation perspective. Journal of Consumer Research, 11(4), 954-961. doi:10.1086/209029 
Kaikati, J. G. (1987). Celebrity advertising: a review and synthesis. International Journal of Advertising, 6(2), 93-105. doi:10.1080/02650487.1987.11107007

Kang, J., \& Choi, W. J. (2016). Endorsed sustainable products: The role of celebrity ethicality and brand ethicality. Clothing and Textiles Research Journal, 34(4), 303-319. doi:10.1177/0887302X16658345

Khan, M. M. (2018). The effect of celebrity endorsement on consumer purchase intention-evidence from q mobile linq advertisement. Pakistan Business Review, 19(4), 1065-1082. doi:10.22555/pbr.v19i4.1882

Koç, E. (2016). Tüketici Davranışı ve Pazarlama Stratejileri Global ve Yerel Yaklaşım (Vol. 7. Baskı). Ankara: Seçkin Yayıncılık.

Lafferty, B. A., \& Goldsmith, R. E. (1999). Corporate credibility's role in consumers' attitudes and purchase intentions when a high versus a low credibility endorser is used in the ad. Journal of Business Research, 44(2), 109-116. doi:10.1016/S0148-2963(98)00002-2

Lohneiss, A., \& Hill, B. (2014). The impact of processing athlete transgressions on brand image and purchase intent. European Sport Management Quarterly, 14(2), 171-193. doi:10.1080/16184742.2013.838282

Louie, T. A., \& Obermiller, C. (2002). Consumer response to a firm's endorser (dis) association decisions. Journal of Advertising, 31(4), 41-52. doi:10.1080/00913367.2002.10673684

MacKenzie, S. B., Lutz, R. J., \& Belch, G. E. (1986). The role of attitude toward the ad as a mediator of advertising effectiveness: A test of competing explanations. Journal of Marketing Research, 130-143. doi:10.1177/002224378602300205

Mansour, I. H. F., \& Diab, D.M.E. (2016). The relationship between celebrities' credibility and advertising effectiveness: The mediation role of religiosity. Journal of Islamic Marketing, 7(2), 148-166. doi:10.1108/JIMA-05-2013-0036

McCormick, K. (2016). Celebrity endorsements: Influence of a product-endorser match on Millennials attitudes and purchase intentions. Journal of Retailing and Consumer Services, 32, 39-45. doi:10.1016/j.jretconser.2016.05.012

McCracken, G. (1989). Who is the celebrity endorser? Cultural foundations of the endorsement process. Journal of Consumer Research, 16(3), 310-321. doi:10.1086/209217

Mikuláš, P., \& Světlík, J. (2016). Execution Of Advertising And Celebrity Endorsement. Communication Today, 7(1), 92-103. https://web.b.ebscohost.com/ehost/pdfviewer/pdfviewer?vid=0\&sid=3343318a7340-49b3-aa53-e9055f4ec0ff\%40pdc-v-sessmgr04

Mishra, A. S., Roy, S., \& Bailey, A. A. (2015). Exploring brand personality-celebrity endorser personality congruence in celebrity endorsements in the Indian context. Psychology ve Marketing, 32(12), 11581174. doi:10.1002/mar.20846

Min, J. H. J., Chang, H. J. J., Jai, T.-M. C., \& Ziegler, M. (2019). The effects of celebrity-brand congruence and publicity on consumer attitudes and buying behavior. Fashion and Textiles, 6(10), 1-19. doi:10.1186/s40691-018-0159-8

Mittal, M. (2017). Attractiveness of Celebrity Endorsed Advertisements, Brand Acceptance, Brand Recall and Buying Behavior: An Empirical Study. Pacific Business Review International, 10(2), 53-63. http://www.pbr.co.in/2017/2017_month/August/5.pdf 
Munnukka, J., Uusitalo, O., \& Toivonen, H. (2016). Credibility of a peer endorser and advertising effectiveness. Journal of Consumer Marketing, 33(3), 182-192. doi:10.1108/JCM-11-2014-1221

Ong, Z. Q., \& Ong, D. L. T. (2015). The impact of celebrity credibility on consumer's purchase intention toward the footwear industry in Malaysia: The mediating effect of attitude toward advertisement. Information Management and Business Review, 7(4), 55-63. doi:10.22610/imbr.v7i4.1163

Paskins, Z., John, H., Hassell, A., \& Rowe, I. (2010). The perceived advantages and disadvantages of regional audit: a qualitative study. Clinical Governance: An International Journal, 15(3), 200-209. doi:10.1108/14777271011063832

Pornpitakpan, C. (2004). The effect of celebrity endorsers' perceived credibility on product purchase intention: The case of Singaporeans. Journal of International Consumer Marketing, 16(2), 55-74. doi:10.1300/J046v16n02_04

Pradhan, D., Duraipandian, I., \& Sethi, D. (2016). Celebrity endorsement: How celebrity-Brand-User personality congruence affects brand attitude and purchase intention. Journal of Marketing Communications, 22(5), 456-473. doi:10.1080/13527266.2014.914561

Roll, M. (2015). Successful Asian Brand Cases. Asian Brand Strategy (pp. 141-182): Springer. doi: 10.1057/9781137359179_7

Roper, S., \& Shah, B. (2007). Vulnerable consumers: the social impact of branding on children. Equal Opportunities International, 26(7), 712-728. doi:10.1108/02610150710822339

Ross, R. P., Campbell, T., Wright, J. C., Huston, A. C., Rice, M. L., \& Turk, P. (1984). When celebrities talk, children listen: An experimental analysis of children's responses to TV ads with celebrity endorsement. Journal of Applied Developmental Psychology, 5(3), 185-202. doi:10.1016/0193-3973(84)90017-0

Roy, S., \& Bagdare, S. (2015). The role of country of origin in celebrity endorsements: integrating effects of brand familiarity. Journal of Global Marketing, 28(3-5), 133-151. doi:10.1080/08911762.2015.1073413

Seno, D., \& Lukas, B. A. (2007). The equity effect of product endorsement by celebrities: A conceptual framework from a co-branding perspective. European Journal of Marketing, 41(1/2), 121-134. doi:10.1108/03090560710718148

Shimp, T. A. (2003). Advertising ve Promotion Supplemental Aspect of Integrated Marketing Communication Penerj. Revyani Sjahrial ve Dyah Anikasari. Jakarta: Erlangga.

Solomon, M. R. (2014). Consumer behavior: Buying, having, and being. Engelwood Cliffs, NJ: Prentice Hall.

Spears, N., \& Singh, S. N. (2004). Measuring attitude toward the brand and purchase intentions. Journal of Current Issues ve Research in Advertising, 26(2), 53-66. doi:10.1080/10641734.2004.10505164

Spielman, H., \& Hayes, S. (1981). The celebrity sell: Making it work/key words in booking stars: realism, budget, audience/speaker fit. Marketing Times, 28(6), 12.

Spry, A., Pappu, R., \& Bettina Cornwell, T. (2011). Celebrity endorsement, brand credibility and brand equity. European Journal of Marketing, 45(6), 882-909. doi:10.1108/03090561111119958

Strauss, A., \& Corbin, J. M. (1990). Basics of qualitative research: Grounded theory procedures and techniques: Sage Publications, Inc. 
Suegker, B. (2003). Lifestyles of the Fit and Famous. Biography, 7(1), 60-65.

Tek, Ö. B., \& Özgül, E. (2013). Modern Pazarlama İlkeleri Uygulamalı Yönetimsel Yaklaşım, Birleşik Matbaacilık 4. Baskı, İzmir.

Thwaites, D., Lowe, B., Monkhouse, L. L., \& Barnes, B. R. (2012). The impact of negative publicity on celebrity ad endorsements. Psychology \& Marketing, 29(9), 663-673. doi:10.1002/mar.20552

Till, B. D., Stanley, S. M., \& Priluck, R. (2008). Classical conditioning and celebrity endorsers: An examination of belongingness and resistance to extinction. Psychology \& Marketing, 25(2), 179-196. doi:10.1002/mar.20205

Tingchi Liu, M., Huang, Y.-Y., \& Minghua, J. (2007). Relations among attractiveness of endorsers, matchup, and purchase intention in sport marketing in China. Journal of Consumer Marketing, 24(6), 358-365. doi:10.1108/07363760710822945

Tripp, C., Jensen, T. D., \& Carlson, L. (1994). The effects of multiple product endorsements by celebrities on consumers' attitudes and intentions. Journal of Consumer Research, 20(4), 535-547. doi:10.1086/209368

Twedt, D. W. (1967). How does brand awareness-attitude affect marketing strategy? Journal of Marketing (pre1986), 4(31), 64. doi:10.1177/002224296703100414

Voss, K. E., Spangenberg, E. R., \& Grohmann, B. (2003). Measuring the hedonic and utilitarian dimensions of consumer attitude. Journal of Marketing Research, 40(3), 310-320. doi:10.1509/jmkr.40.3.310.19238

Yaxuan, R., Jiani, L., Yishi, Z., \& Haiying, W. (2020). The magic of one person: The effect of the number of endorsers on brand attitude. Acta Psychologica Sinica, 52(3), 371-385. doi:10.3724/SP.J.1041.2020.00371

Zarantonello, L., \& Schmitt, B. H. (2013). The impact of event marketing on brand equity: The mediating roles of brand experience and brand attitude. International Journal of Advertising, 32(2), 255-280. doi:10.2501/IJA-32-2-255-280

Zhou, L., \& Whitla, P. (2013). How negative celebrity publicity influences consumer attitudes: The mediating role of moral reputation. Journal of Business Research, 66(8), 1013-1020. doi:10.1016/j.jbusres.2011.12.025

Zhu, X., Teng, L., Foti, L., \& Yuan, Y. (2019). Using self-congruence theory to explain the interaction effects of brand type and celebrity type on consumer attitude formation. Journal of Business Research, 103, 301309. doi:10.1016/j.jbusres.2019.01.055 